\title{
Low urinary counts of P-fimbriated Escherichia coli in presumed acute pyelonephritis
}

\author{
I BOLLGREN, C F ENGSTRÖM, M HAMMARLIND, G KÄLLENIUS, H RINGERTZ, \\ AND S B SVENSON \\ Departments of Paediatrics and Paediatric Radiology, Sachs' Children's Hospital; Department of \\ Bacteriology, National Bacteriological Laboratory; Departments of Paediatrics and Bacteriology, Karolinska \\ Hospital; and Karolinska Institute, Stockholm, Sweden
}

SUMmARY We report 6 children who showed clinical symptoms and laboratory signs of acute pyelonephritis but in whom bacteriuria was insignificant, with Escherichia coli $10 \% \mathrm{ml}$, or less. None of the children had symptoms of other disease. Three of the children who were at first treated inadequately or were not treated with antibiotics developed significant bacteriuria later on $\left(10^{5} / \mathrm{ml}\right.$, or greater). Ultrasonic scanning to evaluate kidney involvement at the acute phase of disease showed transient changes in four of the 6 children-dilatation of one or both pelves or increased ecogenicity of the renal sinus, or both. The urinary $E$ coli strains isolated from all 6 children were P-fimbriated, as determined by a P-fimbriae specific particle agglutination test (PPA test). P-fimbriated $E$ coli are known to be strongly associated with acute non-obstructive pyelonephritis in children and we suggest that the finding of any number of P-fimbriated $E$ coli in the urine of children with clinical evidence of acute pyelonephritis supports this clinical diagnosis.

Urinary tract infection (UTI) is routinely diagnosed by the finding of appreciable numbers of bacteria in urine specimens. In his original report on bacteriuria in adults, Kass clearly pointed out that the commonly used value of $10^{5}$ organisms $/ \mathrm{ml}$ urine is a statistically defined limit only, and that urinary tract infections may exist where there are lower urinary bacterial counts. ${ }^{1}$ Recently Stamm et $a l^{2}$ found by bladder aspiration that about $50 \%$ of women with symptomatic lower urinary tract infections had bacterial counts less than $10^{5} / \mathrm{ml}$ urine. Earlier, Andersen $e t \mathrm{al}^{3}$ using indirect evidence for urinary infections such as presence of high anti Escherichia coli antibody titres and lowered renal concentration capacity, suggested that symptomatic febrile urinary tract infections in children may also be associated with low counts of bacteria in urine. During the first month of life clinical symptoms may precede considerable bacteriuria by several days. ${ }^{4}$

Since a clinical diagnosis of UTI with low urinary bacterial counts sometimes occurs there is a need for laboratory methods that can support the clinical diagnosis. We have previously shown that more than $90 \%$ of acute, first time, non-obstructive episodes of pyelonephritis in children are caused by $\mathrm{P}$ - fimbriated $E$ coli. ${ }^{5}$ P-fimbriae enable the bacteria to adhere to uroepithelial cells by specific recognition of cellular receptors containing the $\alpha$-D-galactose(1-4)- $\beta$-D-galactose carbohydrate structure. ${ }^{6} \quad P$ fimbriated bacteria were also found to dominate the faecal flora of the diseased children. ${ }^{5}$ In healthy controls P-fimbriated bacteria are the dominating $E$ coli strain in less than two percent. ${ }^{5}$ The finding of P-fimbriated $E$ coli in faeces of children with suspected urinary tract infection thus supports this diagnosis.

We report on the use of a newly developed test, the P-fimbriae-receptor specific particle agglutination test (PPA test), ${ }^{7}$ for P-fimbriated $E$ coli in patients with suspected clinical pyelonephritis but with low urinary bacterial counts. In addition to the conventional clinical evaluation of the children, ultrasound scanning of the upper urinary tract was performed in each patient at the acute phase of disease.

\section{Patients and methods}

Patients. Six children, aged between 6 months and $4 \frac{1}{2}$ years, with clinical signs of upper urinary tract 
infection, were examined. Initially attention was directed to two girls (cases 1 and 2) who had clinical symptoms that suggested pyelonephritis (case 1 with fever and loin pains, leucocyturia, and raised concentrations of $\mathrm{C}$-reactive protein (CRP) and case 2 with fever of one week's duration and a raised erythrocyte sedimentation rate (ESR)). The initial urine specimens obtained from these girls were, however, judged to be insignificant with $E$ coli $<10^{3} / \mathrm{ml}$.

These two index cases caused us to study children with clinical evidence of pyelonephritisthat is fever without symptoms of any other concurrent infection, raised CRP $(>0.12 \mathrm{mg} / \mathrm{l})$ and leucocyturia $(>20$ white blood cells/high power field), but with low bacteria counts in their initial urine specimens (bacteria $\leqslant 10^{4} / \mathrm{ml}$ ). During a three month period we found four more girls who fulfilled these main criteria.

Microbiological examinations. Urine specimens were collected after careful washing of the external genitalia, and were immediately subjected to dipslide culturing. Parallel culturing was done using the standard loop technique. Faecal samples from four of the children were examined bacteriologically. Colonies of enterobacteriacea were typed biochemically by the API 20E system (API Systems, France). All $E$ coli strains were recultivated on CFA agar 8 and tested for P-fimbriation by the PPA test. ${ }^{7}$

Ultrasound examination. A Technicare Autosector 1 , real time mechanical sector scanner was used to visualise the kidneys. Scanning was performed with 5.0 or $7.5 \mathrm{MHz}$ transducers, depending on age of the child. The highest frequency transducer that would penetrate adequately to define the kidney in each position was used. The examinations were performed with the children in supine and prone positions. In supine position the liver was used as an acoustic window to visualise the right kidney, and the left kidney was approached from the flank by scanning through the spleen. In the prone position the kidneys were scanned with transducer parallel or at right angles to the vertebral column.

Several sections of the kidneys were examined in both longitudinal and transverse planes to determine: (1) the width of pelvis and calyceal system, (2) the ecogenicity of the renal sinus, and (3) the ecogenicity of the renal cortex of the right kidney, which was compared in each case with the ecogenicity of the liver parenchyma. ${ }^{9}$ These three ultrasonic assessments of the kidneys were graded twice and independently double blind as normal or increased.

\section{Results}

The two index patients (cases 1 and 2) presented with clinical and laboratory signs of pyelonephritis. Their initial urine specimens, however, showed $E$ coli values of only $10^{2}$ and $10^{3} / \mathrm{ml}$ respectively. Since we know from previous studies that pyelonephritis in the young child is most frequently caused by P-fimbriated $E$ coli, we typed the bacteria from these two samples for P-fimbriation by the PPA test, and both urinary isolates of $E$ coli turned out to be P-fimbriated.

As a result of these two index cases we decided to study a series of children who showed low bacterial counts of $E$ coli in their urine and who displayed clinical signs of acute pyelonephritis-fever, leucocyturia, and raised CRP-with no signs of other concurrent disease. During the period 1 January to 31 March 1983 there were four children who met these criteria (Table 1) and in all of whom the urinary isolates were P-fimbriated $E$ coli. In addition to the routine clinical investigations the children's kidneys were examined by ultrasound. Four of the 6 showed transient abnormal findings, either unilaterally or bilaterally (Table 2). Below we give brief descriptions of each case.

Table 1 Occurrence of P-fimbriated E coli in urine and faeces of 6 girls with clinical signs of acute pyelonephritis but with small urinary bacterial counts

\begin{tabular}{|c|c|c|c|c|c|}
\hline \multirow{2}{*}{$\begin{array}{l}\text { Case } \\
\text { No }\end{array}$} & \multirow[t]{2}{*}{ Age } & \multirow[t]{2}{*}{ Clinical symptoms } & \multirow[t]{2}{*}{ Bacterialml } & \multicolumn{2}{|c|}{ Occurence of P-fimbriated $E$ coli } \\
\hline & & & & Urine & Faeces* \\
\hline $\begin{array}{l}1 \\
2 \\
3 \\
4 \\
5 \\
6\end{array}$ & $\begin{array}{r}46 / 12 \\
7 / 12 \\
12 / 12 \\
7 / 12 \\
12 / 12 \\
10 / 12\end{array}$ & $\begin{array}{l}\text { Fever, malaise, loin pain } \\
\text { Fever } \\
\text { Fever, vomiting } \\
\text { Fever } \\
\text { Fever, vomiting } \\
\text { Recurrent fever }\end{array}$ & $\begin{array}{l}10^{2} \\
10^{3} \\
10^{3} \\
10^{2} \\
10^{3} \\
10^{4}\end{array}$ & $\begin{array}{l}\text { Yes } \\
\text { Yes } \\
\text { Yes } \\
\text { Yes } \\
\text { Yes } \\
\text { Yes }\end{array}$ & $\begin{array}{l}\text { ND }+ \\
\text { ND } \\
\text { ND } \\
6 / 6 \\
6 / 6 \\
6 / 6\end{array}$ \\
\hline
\end{tabular}

* Six colonies of enterobacteriaceae were tested for P-fimbriation.

$\dagger$ This child was colonised with P-fimbriated $E$ coli as the dominating strain in faeces two months after onset of disease. $\mathrm{ND}=$ not done. 
Table 2 Evaluation of ultrasonic examination of the upper urinary tract of children with clinical signs of acute pyelonephritis but with small urinary bacterial counts

\begin{tabular}{llllll}
\hline \multirow{2}{*}{$\begin{array}{l}\text { Case } \\
\text { No }\end{array}$} & $\begin{array}{l}\text { Day after } \\
\text { start of } \\
\text { treatment }\end{array}$ & \multicolumn{2}{l}{ Dilatation of pelvis } & \multicolumn{2}{l}{$\begin{array}{l}\text { Increased ecogenicity of } \\
\text { renal sinus* }\end{array}$} \\
\cline { 5 - 6 } \cline { 5 - 6 } & Right & Left & Right & Left \\
\hline 1 & 3 & Yes & Yes & No & No \\
2 & 3 & No & No & Yes & Yes \\
3 & 1 & No & No & Yes & Yes \\
4 & 1 & No & No & No & No \\
5 & 4 & No & Yes & No & No \\
6 & 8 & No & No & No & No \\
\hline
\end{tabular}

* The ecogenicity of the renal cortex was judged as normal in all patients.

Case 1 (index). The girl was aged 4 years 6 months. In April 1982 she fell ill with fever $\left(40^{\circ} \mathrm{C}\right)$ and loin pains and was treated with nitrofurantoin for 10 days. Urine analysis showed leucocyturia $(>50$ wbc/hpf), her ESR was $33 \mathrm{~mm}$ in the first hour, and standard loop urine culturing showed no bacterial growth. In October 1982 the same symptoms reappeared (fever and loin pains for two days). She had leucocyturia (20-50 wbc/hpf), and her CRP value was notably raised $(375 \mathrm{mg} / \mathrm{l})$. Urine culture with standard loop technique (one specimen) showed no growth and the dipslide from the same specimen showed three colonies of $E$ coli $\left(10^{2} / \mathrm{ml}\right)$. With clinical suspicion of acute pyelonephritis, treatment with co-trimoxazole was started before bacteriological results were obtained, and the symptoms disappeared rapidly. The clinical suspicion of acute pyelonephritis was further supported by the finding that 9 days after she had fallen ill she had a reduced maximal renal concentration capacity $(644 \mathrm{mmol} /$ 1). ${ }^{10}$ Ultrasound examinations performed five days after the onset of symptoms showed bilaterally dilatated pelves and ureters. Excretory pyelography 6 days after onset of fever showed a normal excretion but enlarged swollen kidneys $(+2.0$ and $+3.5 \mathrm{SD}) .{ }^{11}$ The three bacterial colonies found on the dipslide were analysed and turned out to be P-fimbriated $E$ coli. This girl has been treated prophylactically with nitrofurantoin since then and is doing well. Renal maximal concentration capacity was 711 and $988 \mathrm{mmol} / \mathrm{l}$ at 6 weeks and four months respectively after the acute phase of disease. One month after the infection ultrasound scans showed a notably increased ecogenicity whereas the dilatation of the pelves had subsided. Three months after the infection ultrasonic findings were normal and micturition cystography showed bilateral reflux, grade II. A urograph examination five months after the infection showed normal sized kidneys. Repeated faecal specimens over 8 months showed a consistent faecal colonisation with P-fimbriated $E$ coli as the dominating $E$ coli strain, but 11 months after infection no P-fimbriated $E$ coli could be detected.

Case 2 (index). A 7 month old girl with fever $\left(39.5^{\circ} \mathrm{C}\right)$ of 6 days duration and without any other distinct symptoms, was examined four days after her temperature had become normal spontaneously. Her ESR at this time was $49 \mathrm{~mm}$ in the first hour and urine culture showed P-fimbriated $E$ coli, $10^{3} / \mathrm{ml}$ urine. Since pyelonephritis was suspected she was treated with amoxycillin. Antibiotic resistance determination showed, however, that the $E$ coli strain was amoxycillin resistant and treatment was changed on day 15 to co-trimoxazole. At this time she had a P-fimbriated $E$ coli value of $105 / \mathrm{ml}$ urine. Ultrasound examination of the kidneys performed 18 days after the onset of fever and three days after beginning treatment with co-trimoxazole showed increased bilateral ecogenicity of the pelves. Ultrasound examination five weeks later was judged normal. Subsequent urography was also normal and micturition cystography showed a reflux grade III on the right side and a reflux grade I on the left side.

Case 3. A one year old girl had fever $\left(40^{\circ} \mathrm{C}\right)$ and vomited for one day, She had leucocyturia $(>50$ wbc/hpf) and her CRP was raised $(28 \mathrm{mg} / \mathrm{l})$. Routine bacteriological examination showed scanty growth of what was judged to be mixed bacterial flora with organisms $<10^{4} / \mathrm{ml}$. The dipslide, however, showed $E$ coli $103 / \mathrm{ml}$ urine, and these were found to be P-fimbriated. Treatment with co-trimoxazole was started before the results of the routine bacteriological analyses were presented. Ultrasound examinations of the kidneys during the acute phase of the disease showed an increased ecogenicity which had become normal by the next examination 8 weeks later.

Case 4. This girl was aged 7 months. Her twin sister had acute pyelonephritis at the age of 3 months with P-fimbriated $E$ coli and, in spite of prophylaxis with nitrofurantoin, she had a febrile recurrence of UTI with P-fimbriated $E$ coli at the age of 7 months. At the same time our patient had fever $\left(40^{\circ} \mathrm{C}\right)$ but no other symptoms were seen. On the third day after the onset of fever, urine analysis showed leucocyturia ( $>50 \mathrm{wbc} / \mathrm{hpf}$ ) and dipslide showed two colonies of $E$ coli $\left(10^{2} / \mathrm{ml}\right)$ which were P-fimbriated. No treatment was started at this point. On the fifth day, she was still febrile, her CRP value was raised $(22 \mathrm{mg} / \mathrm{l})$, and she had leucocyturia (>50 wbc/hpf). At this time, she was given co-trimoxazole. Urine cultures and dipslide tests showed P-fimbriated $E$ coli $10^{5} / \mathrm{ml}$ urine and her faecal flora was dominated 
by P-fimbriated $E$ coli. Ultrasound examination performed on day five was considered normal, as was subsequent urography but micturition cystography showed bilateral reflux grade II.

Case 5. A girl aged 1 year had a short period of diarrhoea and vomiting after which she was febrile for some days. At presentation, she had leucocyturia ( $>50 \mathrm{wbc} / \mathrm{hpf}$ ) and her CRP value was raised $(36 \mathrm{mg} / \mathrm{l})$. Upper UTI was suspected and treatment with co-trimoxazole was started. Urine samples obtained before treatment showed low numbers of bacteria $\left(E\right.$ coli $\left.10^{3} / \mathrm{ml}\right)$ and the treatment was interrupted after two doses. The $E$ coli strain isolated in low counts was later analysed and turned out to be P-fimbriated. Three days later, she had bacterial counts of $>10^{6} / \mathrm{ml}$ urine with P-fimbriated $E$ coli and treatment was promptly reinstituted. Her faecal flora was also predominantly P-fimbriated $E$ coli. Ultrasound examinations showed a slight dilatation of the left pelvis, which had subsided at follow up 7 weeks later.

Case 6. A 10 month old girl who had had recurrent episodes of short lasting fever with no other symptoms for three months presented at the clinic. Her urine specimen showed no bacterial growth as assayed by the standard loop technique but another examination on the third day after presentation showed a high CRP value $(36 \mathrm{mg} / \mathrm{l})$ and leucocyturia ( $>50 \mathrm{wbc} / \mathrm{hpf}$ ). Urine culture as well as dipslide showed P-fimbriated $E$ coli $\left(10^{4} / \mathrm{ml}\right)$. Treatment with co-trimoxazole was started before the routine bacteriological results were obtained. P-fimbriated $E$ coli were dominant in the faecal sample. Ultrasound examination performed on day 11 after presentation was normal as were urography and micturition cystography examinations, performed 6 weeks later.

\section{Discussion}

We have described 6 children showing clinical symptoms and laboratory signs of acute pyelonephritis, but with what are normally regarded as insignificant numbers of bacteria in their urine specimens at presentation. The chances that bacteria numbering less than $10 \% / \mathrm{ml}$ in voided midstream urine represent true bacteriuria have been reported to be small in women with acute pyelonephritis and asymptomatic bacteriuria. ${ }^{1}{ }^{12}$ In more recent studies, Stamm et al found that approximately $50 \%$ of women with acute symptomatic infection of the lower urinary tract had bacteria $<10^{5} / \mathrm{ml}$ midstream urine. ${ }^{2}$

To our knowledge systematic studies on the relevance of small bacterial counts in urine have not been performed in children. Children aged below 4 years are often heavily colonised periurethrally with enterobacteriae of faecal origin. ${ }^{13}$ in contrast to older, healthy children ${ }^{13}$ and adult women. ${ }^{14}$ Thus, in young children there is a high risk of contamination of urine specimens with bacteria from the periurethral area. Accordingly, the predictive positive value of a finding of low numbers of $E$ coli is likely to be smaller in urine from children than from adults.

The most pertinent way to ascertain a correct diagnosis of bacteriuria in smaller children is to perform a bladder puncture: this was not done in our group of children. Three of the children, however, (cases 2, 4, and 5) who were not treated or inadequately treated, later developed significant bacteriuria with P-fimbriated $E$ coli $>10^{5} / \mathrm{ml}$ urine. In the three other patients, treatment based on the strong clinical signs of acute pyelonephritis was started. We could not therefore further elucidate the problem in these children by renewed urinary cultures or bladder aspirates. The leucocyturia found in all of them supports the assumption of an inflammatory process of the urinary tract.

A diagnosis of UTI is usually made on indirect evidence but a high correlation between renal involvement and the criteria of fever, raised CRP, and ESR has been found. ${ }^{15}$ All 6 children examined in this study fulfilled these criteria.

Excretion pyelography may show oedema of the kidneys in the early phase of an acute pyelonephritis, ${ }^{16}$ but does not otherwise contribute to the localisation of the infection. Among new, non-invasive techniques, ultrasound has been shown to be valuable for the diagnosis of anomalies of the urinary tract. In a study of 50 children with acute pyelonephritis with appreciable bacteriuria $\left(>10^{5}\right.$ / $\mathrm{ml}$ ), ultrasound kidney scans performed during the acute phase showed transient abnormalities (dilatation or increased ecogenicity, or both) in one third of the cases (Ringertz et al unpublisied data). These results should be compared with the findings in the present study where the ultrasound examination showed transient changes in four girls but normal scans in two. These transient changes indicating kidney involvement seem to support the diagnosis of acute pyelonephritis.

The $E$ coli strains found in the urine of all 6 children investigated here were all P-fimbriated. P-fimbriated $E$ coli are found in the urine and as the predominating enterobacteriaceae species in faeces of more than $90 \%$ of children with their first acute pyelonephritis. ${ }^{5}$ By contrast P-fimbriated $E$ coli occur on much lower frequencies in faeces of healthy children. ${ }^{5}$ Thus, the finding of P-fimbriated 
$E$ coli in the urine of all 6 children studied here suggests that they were true cases of upper UTI.

During a three month period in this hospital clinic, 4 children were identified with clinical symptoms of acute pyelonephritis but with low bacterial counts of P-fimbriated $E$ coli in their urine. This compares with the finding during the same period and in the same clinic of 17 children with acute non-obstructive pyelonephritis and bacteriuria $10^{5} / \mathrm{ml}$ at presentation. In these children also, all but one of the infecting urinary strains were identified as P-fimbriated $E$ coli. Thus, four of 21 children with clinical signs of acute pyelonephritis showed insignificant bacteriuria. Rapid identification and treatment and thorough follow up of all patients with acute pyelonephritis reduces the risk of renal damage. ${ }^{17}$ The finding of P-fimbriated $E$ coli in urine may strengthen the clinical diagnosis in patients where criteria are incomplete and thus be of aid in the clinical decision making.

In conclusion, if there are clinical signs of upper urinary tract infections, the finding of any number of P-fimbriated $E$ coli in urine specimens is likely to be of aid in singling out a group of children with acute pyelonephritis who need treatment and follow up.

We thank Professor Jan Winberg, Karolinska Hospital and Karolinska Insitute for helpful discussions. This study was supported by Swedish Medical Research Council grants 19X-765 and $16 \mathrm{P}-635202$.

\section{References}

${ }^{1}$ Kass EH, Finland M. Asymptomatic infections of the urinary tract. Trans Assoc Am Physicians 1956;69:56-64.

2 Stamm WE, Counts GW, Running KR, Fihn S, Turck M, Holmes KK. Diagnosis of coliform infection in acutely dysuric women. N Engl J Med 1982;307:463-8.

${ }^{3}$ Andersen HJ, Bergström T, Lincoln K, Ørskov F,Ørskov I, Winberg $\mathrm{J}$. Studies of urinary tract infections in infancy and childhood. VI. Determination of coli antibody titers in the diagnosis of acute urinary tract infections lacking the usual urinary findings. $J$ Pediatr 1965;67:1081-8.

${ }^{4}$ Bergström T, Larsson $\mathrm{H}$, Lincoln $\mathrm{K}$, Winberg J. Studies of urinary tract infections in infancy and childhood. XII. Eighty consecutive patients with neonatal infection. $J$ Pediatr 1972;80:858-66.

5 Källenius G, Möllby R, Svenson SB, et al. Occurrence of P-fimbriated Escherichia coli in urinary tract infections. Lancet 1981;ii:1369-72.

${ }^{6}$ Källenius G, Svenson SB, Möllby R, Cedergren B, Hultberg $\mathrm{H}$, Wintberg J. Structure of carbohydrate part of receptor on human uroepithelial cells for pyelonephritogenic Escherichia coli. Lancet 1981;ii:604-6.

7 Svenson SB, Källenius G, Möllby R, Hultberg H, Winberg J. Rapid identification of P-fimbriated Escherichia coli by a receptor specific particle agglutination test. Infection 1982;10:209-14.

${ }^{8}$ Evans DG, Evans DJ, Jr, Tjoa W. Hemagglutination of human group A erythrocytes by enterotoxigenic Escherichia coli isolated from adults with diarrhoea. Correlation with colonization factor. Infect Immun 1977;18:330-7.

9 Rosenfield AT, Siegel NJ. Renal parenchymal disease: Histopathologic-sonographic correlation. Am J Roentgenol 1981;137:793-8.

${ }^{10}$ Winberg $\mathrm{J}$. Renal function studies in infants and children with acute, non-obstructive urinary tract infections. Acta Paediatr Scand 1959;48:577-89.

${ }^{11}$ Claësson I, Jacobsson B, Olsson T, Ringertz H. Assessment of renal parenchymal thickness in normal children. Acta Radiol [Diagn] (Stockh) 1981;22:305-14.

12 Kass EH. Chemotherapeutic and antibiotic drugs in the management of infections of the urinary tract. Am J Med 1955;18:764 81.

${ }^{13}$ Bollgren I, Winberg J. The periurethral aerobic bacterial flora in healthy boys and girls. Acta Paediatr Scand 1976;65:74-80.

14 Stamey TA, Timothy M, Millar M, Mihara G. Recurrent urinary infections in adult women: the role of introital enterobacteria. California Medicine 1971;115:1-19.

15 Jodal U, Lindberg U, Lincoln $\mathrm{K}$. level diagnosis of symptomatic urinary tract infections in childhood. Acta Paediatr Scand 1975;64:201-8

16 Little PJ, McPherson DR, de Wardener HE. The appearance of the intravenous pyelogram during and after acute pyelonephritis. Lancet 1965;ii:1186-8.

17 Winberg J, Bollgren I, Källenius G, Möllby R, Svenson SB Clinical pyelonephritis and focal scarring: a selective review of pathogenesis, prevention and prognosis. Pediatr Clin North Am 1982;29:801-4.

Correspondence to Dr I Bollgren, Sachs' Children's Hospital, 1169, Stockholm, Sweden.

Received 1 October 1983

(The subject of P-fimbriated bacteria in kidney disease is discussed by Professor Jan Winberg on pages $180-4$ of this issue.) 